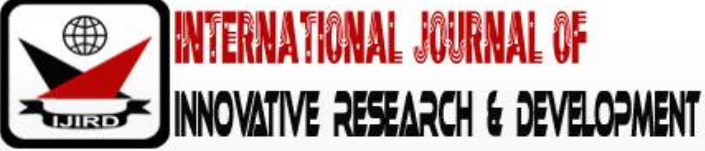

ISSN 2278 - 0211 (Online)

\section{Sustainability of Agronomic Practices Implemented by Millennium Villages Project: A Case of Sauri Millennium Village Cluster, Kenya}

\begin{tabular}{|c|}
\hline Colletah Awino Omondi \\
M.Sc. Student, Department of Community Development Studies, \\
Egerton University, Kenya \\
Susan Muthoni Kamuru \\
Senior Lecturer, Department of Applied Community Development Studies, \\
Egerton University, Kenya \\
Catherine Ngèndo Munyua \\
Senior Lecturer, Department of Applied Community Development Studies, \\
Egerton University, Kenya \\
\hline
\end{tabular}

\begin{abstract}
:
Project sustainability is a major concern in many developing countries. A number of projects that have been implemented fully have been of little benefit to the community since most have proved to be unsustainable. Millennium Villages Project (MVP) was started to fast track the reduction of poverty especially in rural villages where majority of the world poor reside. In 2004 Sauri, Kenya was selected to be the first millennium village in Africa. The purpose of this study therefore was to find out whether the poverty reduction interventions implemented in the Sauri Millennium Village (MV) cluster by the MVP were sustained or not by the beneficiaries beyond the implementation stage. A total of 150 farmers were selected through systematic random sampling from the MVPs register for the year 2012. A researcher operated questionnaire was used to interview the respondents. Data was analyzed using both descriptive and inferential statistics with the help of Statistical Package for Social Sciences (SPSS) version 21. The results of the study indicated that most farmers continued to use the improved agronomic practices after the project closure. This is because the project package fitted within their conventional farming activities and therefore easy to adopt and sustain.
\end{abstract}

Keywords: Sustainability, agronomy, projects

\section{Introduction}

Project sustainability is a major concern in many developing countries(Khan, 2000). A number of projects that have been fully implemented have been of little benefit to the community since most have proved to be unsustainable (ElAlawa, 2013; Kitivi, 2011; Rudqvist, Christoplos \&Lilfelund, 2008). The Millennium Villages Project(MVP) was started to fast track the reduction of poverty especially in rural villages where the majority of the World`s poor reside. In July 2004, Sauri, Kenya was selected to be the first Millennium Village (MV) in Africa with survey beginning in January 2005 and project launched in 2006 (Mutuo et al., 2007). According to the MVP designers, sustainability within the MVP meant that when the MVP stopped, the project beneficiaries would be able to continue their economic progress without a drop in living standard or a decline in social services (Buse, Ludi \& Vigneri, 2008). In this paper sustainability is defined as continuation of project activities after phase out of donor support (Mazibuko, 2007). In Sauri MV farmers were trained prior to the beginning of key activities. In these training sessions agricultural extension agents and MVP agriculture facilitators taught groups of about 100 farmers. The training sessions focused on land preparation, fertilizer placement and plant spacing, application of top dressing, harvesting and post-harvest management here referred to as agronomic practices (Sanchez et al., 2007). The farmers were also trained on use of improved farm inputs specifically improved seeds and inorganic fertilizers besides building their capacity on entrepreneurship skills.

\subsection{Study Area}

Data used in this paper was collected from three wards of Yala division in Gem sub-county, Siaya County, Kenya. The study area comprised of 10 Millennium Villages (MVs) which made up the Sauri MV cluster. These villages were Marenyo, Nyamninia and Sauri in Yala Township ward, Gongo, Nyandiwa and Nyawara in central Gem ward and Lihanda, Ramula and Uranga in East Gem ward. This area is 1400-1500 metres above sea level, west of Rift Valley and $30 \mathrm{~km}$ north of Lake Victoria. It is classified as sub-humid tropics with an average temperature of $24^{\circ} \mathrm{C}$ and annual rainfall of 1800 millimetres per annum. The topography of the area is undulating with ephemeral streams, rivers and wetlands 
meandering through rounded hills. Maize was the major staple crop in the area and the area was classified under mixed maize farming (Mutuo et al., 2007).

\subsection{Objectives}

The specific objective of this paper was to:

Establish the difference between the level of use of agronomic practices introduced by the MVP at the time of project closure in2012 and five years later in 2017

\section{Methodology}

\subsection{Research Design, Population and Sampling Procedure}

A descriptive survey was adopted for the study. A survey design provides quantitative or numeric description of trends, attitude or opinions of a population by studying a sample of the population (Creswell, 2009). Survey strategy also allows one to collect data which can be analyzed using descriptive and inferential statistics (Saunders, Lewis \& Thornhill, 2009). This study used descriptive survey to collect both quantitative and qualitative data on sustainability of recommended agronomic practicesin Sauri MV five years after the termination of the MVP in 2012. The design was appropriate as it enabled the researcher to find out whether or not the farmers had continued to use the recommended agronomic practices. This allowed the researcher to collect data that could be analyzed using both descriptive and inferential statistics (Saunders, Lewis \& Thornhill, 2009). A sample size of 150 household heads was selected using systematic random sampling. This was appropriate because the margin of error was below $10 \%$, as given by a*z/ $\sqrt{n}$ (Creswell, 2014). Oso \& Onen (2009) portend that an acceptable margin of error used by survey researchers falls between 5 and 15\% at 95\% confidence level. Proportionate sample for each of the 10 MVs was got as summarized in table 1

\begin{tabular}{|c|c|c|c|}
\hline Location & MV & $\begin{array}{c}\text { Number Of } \\
\text { Households }\end{array}$ & $\begin{array}{c}\text { Number of Respondents/ } \\
\text { Households Per Village }\end{array}$ \\
\hline Central Gem & Gongo & 1011 & 12 \\
\hline & Nyawara & 976 & 11 \\
\hline & Nyandiwa & 1299 & 15 \\
\hline East Gem & Lihanda & 1311 & 16 \\
\hline & Uranga & 1103 & 13 \\
\hline & Ramula & 1660 & 20 \\
\hline Yala Township & Nyamninia & 1192 & 14 \\
\hline & Jina & 1287 & 15 \\
\hline & Sauri & 1105 & 13 \\
\hline & Marenyo & 1738 & 21 \\
\hline & \multicolumn{2}{|l}{12682} & 150 \\
\hline Total & \multicolumn{2}{|l}{} \\
\hline
\end{tabular}

\subsection{Instrumentation}

A researcher operated questionnaire was used to collect the required data from the selected respondents. This instrument offered the respondents the opportunity to effectively clarify the questions. This instrument offered the researcher the opportunity to effectively clarify the questions. This was important because the literacy level of the respondents was low and clarification of the study items was needed to enhance understanding. A draft of the instrument was given to the supervisors, who were experts in research at Egerton University to determine the clarity and adequacy of the instrument in order to ascertain its construct validity (Wiersma, 1995). The suggestions given by the supervisors were incorporated in to the second draft of the instrument which was pilot-tested in Anyiko which is one of the MVs in the cluster. This was done to establish the reliability of the instrument. Pilot-testing was also done to establish the clarity and comprehensibility of each item in the research instrument and determine the time needed to complete and get the necessary information from the respondents (Ali-Olubandwa, Odero-Wanga, Kathuri \& Shivoga, 2010).

\subsection{Data Collection}

A research permit was obtained from the National Commission of Science, Technology and Innovation (NACOSTI) through the Graduate School of Egerton University. Data was collected through face to face interview using a researcher administered questionnaire. Secondary data was collected by literature review based on the relevant objectives and systematic inferences from the Sauri MV cluster annual evaluation reports of up to 2012, theses and internet sources of relevance to the area of study.

\subsection{Variables of the Study and Data Analysis}

Variables of the study- the independent and dependent variables were the level of use of recommended agronomic practices at the time of project closure in 2012 and five years later in 2017 respectively. Data was analyzed using both descriptive and inferential statistics. For descriptive statistics included frequencies and percentages were used to describe the respondents` bio-data. For inferential statistics chi-square version 21 was used to compare the level of use 
of the recommended agronomic practices at the closure of the project in 2012 and five years later in 2017. Chi square was used to test the independence between the level of use of improved agronomic during and after the project.

\section{Results and Discussions}

\subsection{Household Heads 'Profile}

Majority of the households, 58 percent, were headed by females while 42 percent were headed by males. Of the females in the cluster, 48.64 percent were widows. According to GOK (2014), women marry men who are about five years older and therefore women are more likely to outlive their husbands. Secondly, some families in Sauri were in polygamous marriages where the death of one man would leave behind more than one widow. The general education level in the area was low with 78.7 percent of the household heads having gone to school for eight years or less. Only 21.2 percent of the respondents had secondary education and above while only 5.5 percent of the respondents had post-secondary education. On the basis of agea good proportion of the respondents were elderly as only 18.1 percent of the respondents were aged 45 years and below. This can be attributed to the fact that the MVP had targeted and trained household heads leaving out a number of youths who were by then part of their parents' households. The Sauri MV cluster community is predominantly made up of farmers because 78.7 percent of those interviewed had farming as their only economic activity.

\subsection{Adoption of Recommended Agronomic Practices}

The objective of the study was to establish the difference between the adoption of agronomic practices in Sauri MV cluster at the closure of the project (2012) and five years after the closure (2017). The agronomic practices included; timely seedbed preparation, correct plant spacing, fertilizer application, soil and water conservation, land fallowing, harvesting and post-harvest handling.

\subsection{Training on Agronomic Practices}

The study first sought to establish the number of farmers who actually received training on agronomic practices during the MVP. Figure 2 shows the representation of training on agronomic practices.

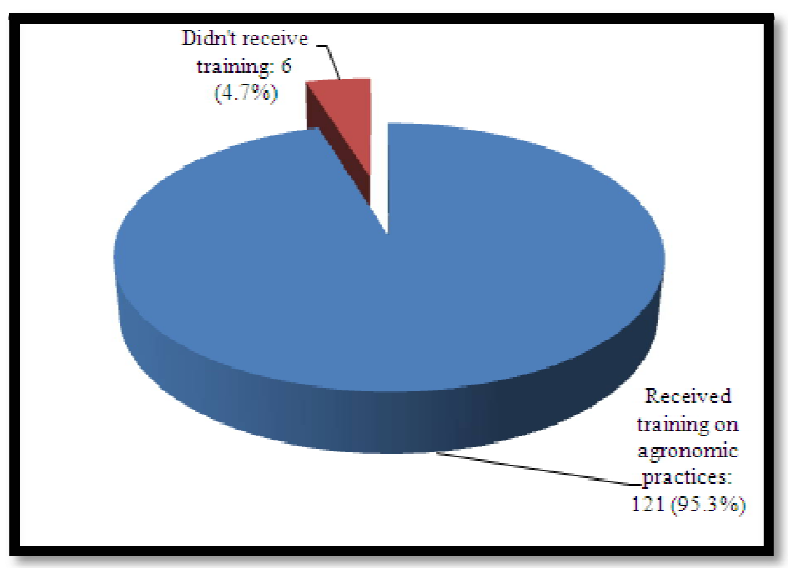

Figure 1: Training on Agronomic Practices

Most of the respondents (95.3\%) were trained on the agronomic practices during the MVP. The specific areas of agronomic practices included soil and water conservation, fallowing, early seedbed preparation, fertilizer placement, timely planting; correct spacing, harvesting and post-harvest handling. The respondents were asked whether they were still applying the eight agronomic practices they were trained on in their farms. The results of the survey revealed that out of 121 farmers who had received training on agronomic practices, most of them (89.3\%) were still applying the agronomic practices they were trained on, as shown on Figure 1.

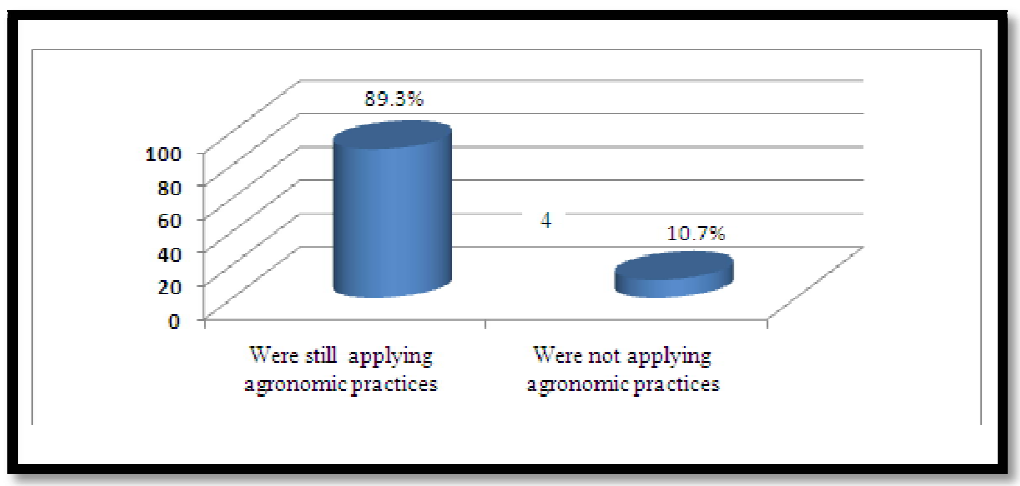

Figure 2: Adoption of Agronomic Practices 
Table 2 summarizes the number of respondents who were trained on various agronomic practices and those who were still applying the practices on their farms by the time of data collection in 2017.

\begin{tabular}{|c|c|c|c|}
\hline $\begin{array}{c}\text { Agronomic Practices } \\
\text { Trained In }\end{array}$ & $\begin{array}{c}\text { No. Practicing in } \\
\mathbf{2 0 1 2}\end{array}$ & $\begin{array}{c}\text { No. Practicing in } \\
\mathbf{2 0 1 7}\end{array}$ & Percentage \\
\hline Early seedbed preparation & 121 & 116 & 95.9 \\
\hline Timely planting & 121 & 116 & 95.9 \\
\hline Correct spacing & 121 & 104 & 85.9 \\
\hline Fertilizer placement & 121 & 102 & 84.3 \\
\hline Soil and water conservation & 121 & 95 & 78.5 \\
\hline Harvesting & 121 & 118 & 97.5 \\
\hline Post-harvest handling & 121 & 116 & 95.9 \\
\hline Fallowing & 121 & 60 & 49.6 \\
\hline Overall Practices & 121 & 108 & 89.3 \\
\hline
\end{tabular}

Table 2: Results on Adoption and Sustained Use of Agronomic Practices Source: Survey Data (2017)

The study established that most of the household heads who were trained but no longer applied the agronomic practices on their farms had varied reasons for not doing so. Correct spacing of maize (the main crop) was based on both inter and intra row spacing. Those who were not practicing were mainly the elderly who explained that those practices were beneficial but laborious. Hence, they could only apply them they had access to hired labor or if they had younger family members to do the work. It is clear that a number of respondents were applying the MVP generated technologies selectively. Harvesting, early seedbed preparation, timely planting and post-harvest handling were being practiced by most of the farmers in 2017. However, five years after the closure of the project it was not exactly the case for small scale soil and water conservation and fallowing. Similar findings were reported by Danso-Abbeam et al.,( 2017) that less complex technologies that require relatively fewer changes to the farmer's current practices are easily adopted. The change in the number of respondents who practiced correct spacing during and after the project closure was attributed to the tedious and difficult nature of the technology, especially for the elderly people. The practice also required slightly more resources in terms of labor costs (Muhungu, 2008).

Although most of the farmers continued with the learnt practices on the agronomy they learnt from the project, a significant proportion of them were not applying the agronomic practices by 2017 . The agronomic practice that was least sustained by the respondents was fallowing of land at 49.6\%. Despite the fact that the project provided farmers with seeds of leguminous shrubs to grow on their farms during the fallow period, (50.4\%) of the respondents did not grow them. The shrubs would fix nitrogen, smother weeds and improve moisture retention in the soil. The findings can be attributed to the fact that most of the respondents had small farm sizes that were planted with food crops throughout the year to meet the family food needs. These findings concur with the report by Kihara et al., (2005) that, as the population pressures cause farm size to shrink over time for most small scale farm households, they respond by continuously cropping their fields every year. Soil and water conservation were least adopted despite their numerous benefits. Semalulu, Magunda, Mabiru, Kaizzi and Komutunga (2017) reported that, practices such as runoff water harvesting, mulching, minimum tillage increase water infiltration, reduce evaporation and store water in soil. These practices improve soil organic matter, structure, porosity and aeration and increase water infiltration, water storage and availability to plants. However, mechanical soil and water conservation structures such as terraces and contour bunds are laborious.

The hypothesis tested was that: There is no statistically significant difference in the use of the agronomic practices in 2012 as introduced by the MVP in Sauri MV cluster and in 2017. Chi Square test of independence was used to test the null hypothesis. The chi square values are summarized in Table 6.

\begin{tabular}{|c|c|c|c|c|c|c|}
\hline Agronomic practices & $\begin{array}{c}\text { Number Practicing } \\
\text { in 2012 }\end{array}$ & $\begin{array}{c}\text { Number } \\
\text { Practicing } \\
\text { in 2017 }\end{array}$ & Df & $\boldsymbol{\chi} \mathbf{2}$ cal. & $\begin{array}{c}\boldsymbol{\chi} \mathbf{2} \\
\text { critical }\end{array}$ & P-value \\
\hline $\begin{array}{c}\text { Early seedbed } \\
\text { preparation }\end{array}$ & 121 & 116 & 1 & 0.207 & 3.841 & 0.063 \\
\hline Timely planting & 121 & 116 & 1 & 0.207 & 3.841 & 0.066 \\
\hline Correct spacing & 121 & 104 & 1 & 2.388 & 3.841 & 0.102 \\
\hline Fertilizer placement & 121 & 102 & 1 & 2.983 & 3.841 & 0.074 \\
\hline Harvesting & 121 & 118 & 1 & 0.074 & 3.841 & 0.112 \\
\hline Post-harvest handling & 121 & 116 & 1 & 0.207 & 3.841 & 0.083 \\
\hline Fallowing & 121 & 60 & 1 & 30.752 & 3.841 & 0.003 \\
\hline Overall Practices & 121 & 108 & 1 & 1.397 & 3.841 & 0.057 \\
\hline
\end{tabular}

Table 3: Summary of Chi Square Results on the Difference between the Use of

Agronomic Practices in 2012 and 2017

Null Hypothesis $\left(\mathrm{H}_{0}\right)$ Accepted at $\mathrm{P}<0.05$ Significant Level

Source: Survey Data (2017) 
Given that each respondent was trained in all the agronomic practices, they were all expected to continue putting them into use after the expiry of the project. The results on table 2 shows, that the number of farmers using various agronomic practices in 2017 was less than those who used the same in 2012. However, this difference was not statistically significant ( $p>0.05, \mathrm{df}=1$ ), meaning that generally in overall, there is no significant difference in the number of farmers who were using the agronomic practices in 2012 and those who were using the same in 2017. This was confirmed by the calculated Chi-square $\left(\chi^{2}\right)=1.397, \mathrm{p}<05$ which is less than the tabulated Chi-square value of 3.841 for the overall application of agronomic practices at significant level $=.05$ at $\mathrm{df}=1$, meaning that generally, there was continued use of the various agronomic practices that were introduced to the farmers. On the other hand, the study established that there was statistically significant difference in two agronomic practices; mainly on the fallowing of land $(\mathrm{P}<.05)$ and small scale soil and water management $(\mathrm{p}<.05)$.

\section{Conclusion and Recommendations}

Most farmers, who had adopted the agronomic practices introduced by the MVP, continued applying the same after the project closure. This was especially so with timely seedbed preparation, timely planting, harvesting and postharvest handling that did not require additional cost or labour. Land fallowing and small scale soil and water management practices were least sustained due to small land sizes and labor demand respectively. This notwithstanding, the Millennium Villages Project in Sauri cluster in Siaya County was relatively well maintained by the beneficiaries. Perhaps due to the trainings given to them before the commencement of the project and secondly the project package fitted within their conventional farming activities and livelihood and therefore easy to adopt and sustain.

The study therefore recommends that in formulation and introduction of agricultural projects to farmers, more consideration should be given to those that do not disrupt their work and livelihood patterns. Additionally adequate training of the project beneficiaries should precede the actual project implementation. Proper monitoring of technology uptake should be a priority to the extension agents to provide the necessary advice.

\section{References}

i. Ali-Olubandwa, A.M., Odero-Wanga, D., Kathuri, N.J., and Shivoga, W. A. (2010). The Influence of Adoption of Improved Maize Production Practices on Maize Yield Among Small Scale Farmers in Western Province in the Agricultural Reform Era. Journal of International Agricultural and Extension Education Vol 17 No.1

ii. Barret, C. B., Reardon, T., and Webb, P. (2001). Non-Farm Income Diversification and Household Livelihood Strategies in Rural Africa: Concepts, Dynamics and Policy Implication.

iii. Buse, F., Ludi, E., and Vigneri, M. (2008). Sustaining and Scaling the Millennium Villages: Moving from Investments to National Goals to reach the MDGs. Nairobi: Overseas Development Institute.

iv. Creswell, J. W. (2014). Research Design: Qualitative, Quantitative and Mixed Methods Approaches (4thed.). Thousand Oaks, CA: Sage

v. De Janvry, A., Sadoulet, E., Graff and Zilberman, (2001). Role of Non-Farm Income in Reducing Rural Poverty and Inequality in China. Journal of Development Studies. Washington DC: World Bank.

vi. El-Alawa, Y. (2013). The Factors Affecting Poverty Alleviation Projects in Developing Economies. Case Study; Urban Poverty Reduction Projects by Social Investment Fund, Ghana. Unpublished thesis, Seinajoki University of Applied Sciences.

vii. Kathuri, N.J. and Pals, D.A. (1993). Introduction to Educational Research. Egerton Education Book Series. Njoro: Egerton University.

viii. Khan, M. A. (2000). Planning and Monitoring of Project Sustainability: A Guide on Concepts, Issues and Tools. Washington DC: United Nations Development Programme.

ix. Kitivi, D.M. (2001). Performance of Poverty Eradication Donor Funded Projects in Mwingi Sub-county, Kenya. Unpublished Masters Thesis. Kenyatta University.

x. Mazibuko, J.B. (2007). Enhancing Project Sustainability beyond Donor Support, an Analysis of Grassroot Democratization as a Possible Alternative. Unpublished master's thesis. University of South Africa.

xi. McArthur, J.W. (2010). Millennium Promise; 2010 Annual Report. New York: The Earth Institute.

xii. Mical, P.A. (2014). Relationship between Entrepreneurship Education and Poverty Reduction among Farmers in Kisumu County, Kenya. Unpublished doctoral dissertation: Kenyatta University- $\quad$ Nairobi,

xiii. Millennium Promise (2011).2011 Annual Report on Millennium Villages Project. New York: The Earth Institute.

xiv. Mutuo, P., Lelerai, E., Okoth, H., Oule. J., Oduong, G., Ombai, W., Wairero, J. ...\& Akinyi, B. (2006). Annual Report for Sauri Kenya Millennium Research Village July 2005-June 2006. New York: The Earth Institute.

xv. Narayan, D., \& Nyamwaya, D. (1996). Learning from the Poor, a Participatory Poverty Assessment in Kenya. Paper No. 0034.Washington DC: World Bank.

xvi. Nziguheba, G., Palm, C.A., Berhe, T., Denning, G., Dicko, A., Diouf, O., \&...Sachs, P. (2010).The African Green Revolution, Results from the Millennium Villages Project. New York: The Earth Institute at Colombia.

xvii. Oso, W. Y., \& Onen, D. (2009). A general Guide to Writing Research Proposals and Report. Nairobi: Jomo Kenyatta Foundation

xviii. Rudqvist, A., Christoplos, I. \& Lilfelund, I. (2008). Poverty Reduction, Sustainability and Learning: an Evaluability Assessment of Seven Area Development Projects, Sida Studies Evaluation 00/ 4.

xix. Sanchez, P., Palm, C., Denning, G., Flor, R., Harawa, R., Juma, B., Kiflemanam...\& Lelerai, E. (2007). The African Millennium Villages. New York: Columbia University. 
xx. Tott, G. (2013). Influence of Donor Funded Projects on the Social Economic Welfare of Rural Communities: Case of Cadsal in Elgeyo Marakwet County, Kenya. Unpublished Masters Thesis.

xxi. UNICEF. (2018). Situation Analysis of Children and Women in Kenya 2017. Nairobi Kenya. UNICEF.

xxii. World Bank. (2005a). Globalization Growth and Poverty. Building an Inclusive World Economy. NewYork: Oxford. University. Press. 